\title{
ADECUACIÓN JUDICIAL DEL SISTEMA DE FUENTES DEL DERECHO OBJETIVO AL HOY Y EL MAÑANA DEL ESTADO DE BIENESTAR
}

\author{
Manuel Ma Zorrilla Ruiz \\ Catedrático Emérito de la Universidad de Deusto \\ Ex-Presidente del Tribunal Superior de Justicia del País Vasco \\ Presidente de la Asociación de Jueces y Magistrados Jubilados de España
}

\begin{abstract}
Sumario. 1. Consideración de orden general. 2. Ejercicio de la jurisdicción universal allende los confines territoriales de las competencias del Estado soberano de hoy día. 3. Conexión que, entre ordenamientos jurídicos, puede establecer la jurisdicción ordinaria sobre la libertad de empresa y sus repercusiones en la suerte del Estado de Bienestar. 4. Importancia de la seguridad jurídica para conseguir, en lo concerniente al Estado de Bienestar, la modernización del sistema de fuentes del Derecho objetivo. 5. Desafíos que ha de afrontar la jurisdicción ordinaria en favor de las oportunidades actuales del Estado de Bienestar. 6. Compromisos que los jueces ordinarios están en condiciones de adquirir para difundir y defender el Derecho justo. 7. Particularidades del complejo sistema de fuentes en el Derecho de las relaciones de trabajo. 8. Plenitud existencial del ordenamiento jurídico en el presente del Estado de Bienestar. 9. Funciones que incumben a los jueces ordinarios para avalar la paz que necesita el Estado de Bienestar. 10. Perspectivas didácticas de la jurisdicción ordinaria en las peripecias del Estado de Bienestar. 11. Relaciones e injerencias de los ordenamientos jurídicos que asumen y defienden los valores del Estado de Bienestar. 12. Bibliografía de orientación.
\end{abstract}

\section{CONSIDERACIÓN DE ORDEN GENERAL.}

El Estado de Bienestar y su programa de progreso irreversible suscitaron el caluroso aplauso de unas aspiraciones colectivas tan vehementes como las que hoy arropan el mito del desarrollo sostenible y antaño abonaron el principio de irregresividad de las adquisiciones sociales de los trabajadores. Su perfección dogmática admitía, ávidamente y sin vacilaciones, la posesión innata de los valores, bienes y derechos que, en pos de aquellos objetivos, resarcían los daños causados a una dignidad individual sojuzgada y deseosa de culminar sus anhelos de liberación. Superados los desvaríos de los regímenes totalitarios y ambientando el panorama de sus innovaciones, el Estado social y democrático de Derecho sirvió de soporte a unas pretensiones inobjetables y atractivas. Dimanaban de la naturaleza de las cosas en los cauces del retorno incesante del orden natural, porque, pensadas para satisfacer esta constante, acreditaban una inquietud a toda prueba en pos del mínimo de justicia material que fundaba sus aspiraciones. Andando el tiempo y cultivando los conceptos indeterminados de naturaleza económica, 
el bienestar se ha transmutado en la serie de pasos al frente o en la suma de las regresiones que, ante las excitantes peripecias históricas, proveen al crecimiento de los bienes buscados y al exterminio de los males temidos. Lo hacen en función de los recursos con que los poderes públicos competentes obsequian a las personas fisicas condenadas a entenderse y coexistir con sus iguales, a las comunidades que se van erigiendo en cuerpo y alma, y a la sociedad pluralista compuesta, como evoca el art. 9.2 CE (Constitución española de 27 de diciembre de 1.978), por los grupos en que, espontánea o reflexivamente, se integra el individuo. Ello acontece en un marco de legalidad positiva que, según los vaivenes del tiempo y del espacio, cambia, a distintos ritmos, los registros que, identificando la totalidad de esa noción, vigilan sus oscilaciones. La inclinación nominalista-que es fiel al fondo de las cosas y propende a llamarlas por su nombre- determina que la etiqueta de Estado de Bienestar haya pasado a designar realidades distintas y distantes de las que, por vez primera, revelaron la generosidad de las ofertas hechas a una sociedad resuelta a enfrentar el desafío de las intimaciones que exclamaban «ilevántate y anda!».

Más allá de su pulcritud académica, el sistema de fuentes del Derecho objetivo ha evolucionado a la hora de verificar la dimensión, la actualidad y la accesibilidad de los derechos, las obligaciones y las situaciones jurídicas que perduran o de súbito surgen en el depósito del Estado de Bienestar. Conscientes de la dificultad de contabilizar sus movimientos, sus partidarios se aferran a un haz de valores residuales o sobrevenidos y apuestan por la tarea de impulsar la supervivencia de aquél en la postura erguida y animosa que requiere una operación de este calibre. Actitud elogiable, si se toma nota de que el Derecho constituido no ha bebido los vientos para rescatar los valores inefables del Estado de Bienestar que se desvanecen y/o dispersan. Ha preferido -como lo atestiguan las impresiones que, a la orden del día, promueven interminables sobresaltos- mirar de soslayo, a lo sumo, y no contrariar las demasías que acreditan el prevalecimiento insolente de la Economía sobre la equilibrada difusión social de un programa que, desahuciado de sus campos de acción, choca con el sinfín de obstáculos que le oponen sus encarnizados enemigos.

Los cambios de identidad de los bienes afectados por estas sustituciones y/o mudanzas se advierten a la luz de nuevas situaciones históricas diagnosticadas con certeza y lo bastante seductoras para que, de una parte, los analistas del fenómeno del Estado de Bienestar reiteren la voluntad de preservar su itinerario y crecimiento irrenunciables, y, de otra, los interesados en sus adelantos no se desmoralicen ante el fracaso de sus apetencias más dilectas. Defienden unas adquisiciones que, acrecentando la pasión de sus orígenes históricos, precisan de una heroicidad descomunal para que, pese a las insidias de la enemistad política, sus afanes no retrocedan un ápice y pregonen, a los cuatro vientos, la pujanza de sus constantes reivindicativas. 
Los valores y bienes residuales que atesora el depósito del Estado de Bienestar, tienen algo que ver con la presentación de las hipótesis que aprovechan la ductilidad fenómenológica del sistema de fuentes del Derecho objetivo.

\section{EJERCICIO DE LA JURISDICCIÓN UNIVERSAL ALLENDE LOS CONFI- NES TERRITORIALES DE LAS COMPETENCIAS DEL ESTADO SOBERA- NO DE HOY DÍA.}

La amplificación territorial del sistema de fuentes del Derecho objetivo proviene de los impulsos emotivos y de las inquietudes intelectualizadas que secundan la doctrina de la jurisdicción universal. Invocan un yusnaturalismo existencial que reitera la tesis del retorno incesante de sus preferencias axiológicas. Se asocian al ejercicio de la modernidad que aboga por el conocimiento punitivo de la jurisdicción penal allende los contornos geográficos de la soberanía del Estado. Positivizando las exigencias del Derecho de Gentes de esa actualidad, los textos internacionales han reafirmado una línea de fuerza que concierne al entendimiento de normas jurídicas cuya aplicación -confiada a los jueces ordinarios- se ha tildado, unas veces, de error excusable -ante la falibilidad humana del enjuiciamiento regido por una disciplina que, como el Derecho Penal, acampa en las comarcas del mundo del valor-y, otras, se ha tachado de extralimitación propia de un comportamiento delictivo doloso, cuyo elemento intencional obedece a vivencias recónditas o a ciertos rasgos de la personalidad que configuran su intrahistoria.

Constan los reparos que echan de menos el título jurídico de atribución de esas competencias, la prueba de su compatibilidad con la unidad de soberanía que trasluce la jurisdicción, la reseña de sus objetivos, el inequívoco enunciado de las garantías ofrecidas y la adopción de mecanismos sancionadores eficaces. La tendencia se encuentra a mitad de camino entre la instintiva adhesión emocional -asumida por las bases de las comunidades-y el impacto de unas demandas sociales convencidas de lo que sus ambiciones son y significan. Hay una irrupción de la voluntad popular -dato invasor que, sin el filtro de una opinión pública homogénea, logra velocidades endiabladas y engendra bastantes desatinos- que considera anacrónicos los obstáculos técnicojurídicos del Derecho constituido y descalifica-cuando no escarnece- a los especialistas que aplican sus normas con sensibilidad y pulcritud. Sus filas no suelen nutrirse de juristas comprometidos y sensatos, pero sí de aficionados de ocasión o ignorantes de primera fila que conciben el ordenamiento jurídico como el pretexto de la dominación de los más fuertes o la antigualla que hay que demoler al antojo de cuantos se dicen estorbados por su incomodidad. Su militancia olvida que, según un principio pacífico, la unidad de jurisdicción es el reflejo que, en el campo procesal, adquiere la unidad de soberanía. Postura que, en su justa medida, no ha de sufrir correcciones que pugnen con la recta razón y el buen sentido. Entienden muchos que esos originales adelantos responden a las invitaciones del 
sano sentimiento popular -etiqueta que, a la luz de sus orígenes históricos, merece alguna que otra revisión-y a los llamamientos del progreso. Como si éste se redujese a una excursión mecanicista, privada de la celosa administración de sus hallazgos y conchabada con cuantos extravíos salgan a su encuentro para compartirse lastimosamente. La obsesión de culminar un fin a cualquier precio enmascara las obnubilaciones del error invencible que emponzoña la licitud de los medios.

La decepción intelectual de los juristas y el escepticismo de la sociedad prueban las frustraciones de un sistema incapaz de reprimir eficazmente las devastaciones de una delincuencia internacionalizada por iniciativas inhumanas y egoísmos inmisericordes. Ya el p. (parágrafo) 23 EMTPC.c. (Exposición de Motivos de la Ley de 31 de mayo de 1.974, que reformó el Título Preliminar del Código Civil) se cercioró del estado de cosas que, ante el peligro de esas amenazas, forzaba a definir el mundo contemporáneo -dispuesto a proteger su identidad-como un conjunto creciente de interacciones a escala internacional y mundial. La que -sin imaginación ingeniosa, abierta a la originalidad de sus fenómenos y estéticamente asociada a su rotulaciónse denominaría después aldea global.

La globalización depredará los adelantos de un antropocentrismo tan fatigoso de arraigar con fortaleza suficiente, como asequible a la voracidad del neoliberalismo salvaje que, simulando restaurar el universo químicamente puro de las libertades, silencia sus escalofriantes compromisos. Pasa a considerarse deleznable cuanto, en pro del respeto debido a la dignidad de la persona individual, entraña un valor colectivo regido por las pautas de la moralidad y la justicia material. Se le reemplaza por el malevolente artificio de convertir en vicios las virtudes -solidaridad, intercomunicación y acercamiento- que constituyen una consecuencia valiosa del empequeñecimiento del mundo. Sobrecoge el afán de destruir, sin un ápice de mala conciencia, los avances que las formas perversas de la globalización condenan a un exterminio selectivo.

Los criterios de la punición irrestricta de la delincuencia supranacional eran el elogiable testimonio de una mundialización destinada a fortalecer la bondad de sus orígenes, aunque -si la perspectiva se afinaba -se atisbasen también los atributos repulsivos de su semblante demoníaco. No en vano sobrevive la ley histórica que reconoce el tránsito del ejercicio templado del poder a las desfiguraciones de su rostro diabólico. Seduce, como contrapeso, la consigna de revigorizar la máxima que reza «allí donde la justicia dé contigo, allí serás juzgado y responderás de tus delitos», cuando un juez territorialmente competente en el interior de un Estado soberano, persigue las infracciones cometidas en un distante rincón del universo, donde las victorias del dogma de la jurisdicción universal se aplauden con el optimismo de la lucha librada contra una especie de criminalidad hasta entonces impune. Los contenidos de estas expectativas acrecientan las intuiciones del Estado de Bienestar apetecible y, en lugar de otras que se desvanecen, modernizan 
el elenco de sus finalidades protectoras. Con todo y ello, el balance final de semejante hoja de ruta no deja de encerrar más de una incógnita.

La atención prestada a los derechos que, desde su advenimiento a este mundo, acompañan a la persona humana y mejoran a causa de la modernidad que les ilustra, se ha de multiplicar para reprimir las agresiones consumadas más allá de los límites territoriales de la soberanía del Estado en que su enjuiciamiento natural debe ocurrir. Nadie duda de que, por muy distantes que entre si se hallen las personas y las cosas, siempre han sido legión los que, bajo el estigma de los ultrajes infligidos a sus cuerpos y almas, se han refugiado en una torre que, allá en la lejanía, acoge sus gemidos y sus lágrimas ante la incapacidad de acabar con tantas desventuras. A todos entristecen el desgaste y la indigencia de un Derecho común que, huérfano de sensibilidad innovadora, no se ha molestado en indagar otros valores atendibles ni ha reparado en el tamaño de las explosiones de insolidaridad, en lo atroz de las abstenciones injustas de resarcimiento inviable, y en lo abrumador de los daños causados omisivamente por la indiferencia, la desmemoria y el olvido. El Estado de Bienestar - cuyo tejido combina notables enriquecimientos con espectaculares defecciones- no se concibe sin que una de sus alternativas de presente resida en el capítulo de una Política Criminal dispuesta a perseguir, sin tregua, la suma de maldades que - cuales la vulneración de los derechos humanos, el despliegue del terrorismo a ultranza y el frenesí morboso de los delincuentes económicos - cavila, planifica y emprende la codicia de los sectores más abyectos de la Humanidad.

El sistema de fuentes del Derecho objetivo ofrece un punto de inflexión que destaca el relieve de la jurisdicción universal. El derecho fundamental de todos al juez ordinario predeterminado en la ley, según el art. $24.2 \mathrm{CE}$, afluye a preceptos procesales que, como el art. 23.3 y 4 LOPJ (Ley Orgánica del Poder Judicial de 1 de julio de 1.985), reseñan los tipos delictivos que ensanchan la competencia territorial de los órganos jurisdiccionales del Estado social y democrático de Derecho. El juez ordinario -consciente del deber de sometimiento al imperio de la ley con que le avisan los arts. 117.1 CE y 1.1 LOPJ- ha de atenerse a las garantías de la seguridad jurídica, del principio de legalidad en materia penal y del derecho a la defensa. Los arts. 9.3, 24.1 y $25.1 \mathrm{CE}$ se han escrito y están donde se encuentran para madurar su memoria y recordarle los inconvenientes de erigirse en un personaje taumatúrgico. No puede asumir -más allá de sus atribuciones interpretativaslos cometidos de otros poderes públicos. Menos aun cabe que, asignándose competencias de excepción, se arrogue -sobre todo en la delicada materia penal- las funciones cuasilegislativas que proscriben la improvisación emocional o demagógica y exigen una pausada reflexión, una sana formación interdisciplinar, una objetividad a toda prueba y una entereza indiscutible. Cierto que los beneficiarios de las acciones - preventivas o terapeúticas- del Estado de Bienestar tienen derecho a que los jueces ordinarios les garanticen la cuota de paz social amenazada por las irradiaciones de la delincuencia 
internacional que se combate. Quienes entonces hacen gala de un talante revolucionario y dicen auxiliarse del uso alternativo del Derecho, olvidan que, según la disección de estos conceptos, deben darse las condiciones de ponderación y de templanza que demuestren estar en posesión de dicha cualidad. Los textos inventores de la Magistratura contemporánea distinguieron lo que la función de administrar justicia tenía de emocionalmente irreprimible - no en vano la voz sentencia data del infinitivo latino sentire-y el desvario de las turbas de juristas que, hollando el imperio del Derecho, comulgaban a ciegas con la sinrazón y ensalzaban los envilecimientos del error. Los pobladores del Estado de Bienestar tienen derecho a que los jueces ordinarios les garanticen el sector de paz social avalada por la aplicación - excepcionalmente extraterritorial- de unas normas penales dictadas para recobrar los valores y bienes que se les han arrebatado.

\section{CONEXIÓN QUE, ENTRE ORDENAMIENTOS JURÍDICOS, PUEDE ESTA- BLECER LA JURISDICCIÓN ORDINARIA SOBRE LA LIBERTAD DE EM- PRESA Y SUS REPERCUSIONES EN LA SUERTE DEL ESTADO DE BIEN- ESTAR.}

El principio de primacía del Derecho comunitario se entiende a la luz de su misión vertebradora del ordenamiento jurídico que le convierte en clave de su razón de ser y su eficiencia. Significa que, amén de la preponderancia de las normas de Derecho europeo sobre las del mismo marco que se le subordinan, ninguno de los Estados miembros de la UE (Unión Europea nacida del Tratado de Maastricht o Mastrique de Flandes de 9 de febrero de 1.992) puede desnaturalizar o deprimir el carácter de una institución a la que asiste la preeminencia propia de aquella jerarquía. Denota la superioridad categórica o el rango que sus normas ostentan respecto a las demás integrantes de un todo que las asimila y engloba. Condicionan también sus peculiaridades y su fisonomía.

Una de las funciones sociales de la libertad de empresa -referida a la economía de mercado en el art. $38 \mathrm{CE}$ - impone a los empleadores unas cargas que coexisten con los dictados de la flexibilidad y la justificación del ejercicio de la resistencia frente a los abusos globalizadores. Han de asumir riesgos extraordinarios - a que antaño no les apremiaban los acontecimientos críticos de la Economía- y cursar, sin el brazo encogido, sus ofertas de empleo a los demandantes provistos de una fuerza de trabajo idónea para solicitar y obtener ocupación en los azaroso yacimientos de los ciclos productivos que, andando la crisis y a fin de atenuar sus consecuencias, se estrenan, reconvierten o combinan ambas posibilidades. La libertad de establecimiento y la libre circulación de capitales son derechos fundamentales de la UE que -como base y fundamento de una gobernación equilibradaincorporan los contenidos innatos pertenecientes a sus destinatarios, a los órganos públicos de la UE y a sus posteridades respectivas. Así se impiden las rebajas con que -cediendo a flaquezas reprobables- el Derecho interno 
de los Estados miembros intente vaciar aquellas libertades en reductos de inferior nivel o jerarquía.

He aquí todo lo contrario de manejar el art. $38 \mathrm{CE}$ como un instrumento de quién sabe qué ligerezas o arbitrios que, sorteando el gravamen impuesto en el art. 33.2 CE, violan el contenido esencial o núcleo invulnerable del derecho constitucional afectado por sus vicisitudes. Distinto es aferrarse a razones de urgencia que le afectan arguyendo el sometimiento a un orden público económico que la UE segrega, casuística y asistemáticamente, por goteo y que cobra espeluznantes dimensiones a causa de los sucesos relativos a la entereza de la moneda única y a las convulsiones especulativas que esta cuestión desencadena. Las libertades de establecimiento y circulación de capitales son derechos fundamentales de la UE, sin cuyo acicate y actuación -inseparables del pasado, el presente y el futuro de las instituciones comunitarias- se resquebrajaría el ordenamiento jurídico europeo, harto afligido por la insolidaridad continental. Si se degrada la libertad de empresa que el art. $38 \mathrm{CE}$ reconoce en el ámbito de la economía de mercado, se conculca la interdicción de la primacía del Derecho comunitario que prohibe asignarle un rango y una cualificación inferiores a los que le corresponden en el marco jurídicoeconómico de la Europa integral. Se adultera su naturaleza si -como hace la sec. $2^{\mathrm{a}}$, cap. $2^{\mathrm{o}}$, tít. CE- se apela al nominalismo genérico que la considera uno más de los derechos y deberes de los ciudadanos. Ello es tanto como eximir a sus titulares del papel que les incumbe en el tratamiento de una recesión económica que amenaza, irrumpe o aumenta de tamaño. Se desactivaría una carga imprescindible para paliar los males de la sociedad y evitar la degradación de un empleo castigado por las lacras que aumentan el ritmo de su destrucción acelerada. ¿Se dará, alguna vez, con las claves profundas y ocultas de estas aberraciones?

De la sensibilidad de los jueces ordinarios depende adherirse a la tesis que -fundada en el enfoque finalista del principio de primacía del Derecho Comunitario- confiere a la libertad de empresa el carácter de derecho fundamental que le ha rehusado el legislador constituyente. La conclusión coincide con los criterios de la opinión pública y las demandas sociales que, al respecto, no yerran ni vacilan. He aquí una sugerencia de reforma constitucional innominada, fruto de las iniciativas judiciales que, acogidas al art. 9.2 $\mathrm{CE}$, removerían no pocos de los impedimentos obstantes a la buena marcha de la economía general. A imitación de las libertades sindicales individuales y colectivas, la libertad de empresa -motor del cambio imprescindible para paliar los contratiempos de un catastrófico presente o salvar el mobiliario de la economía- gozaría de la tutela reforzada que el art. 51.2 CE confiere a los derechos fundamentales. Los novedosos compromisos de la libertad de empresa recuerdan el revuelo que -bajo la pintoresca etiqueta de vedette del Derecho en los ambientes adelantados de su tiempo- provocaron la recepción y el estudio de las cuestiones relativas a la responsabilidad civil. Urge componer un cuadro de reproches y responsabilidades -inclusive penales- 
que sancione la deserción de cuantos -titulándose emprendedores a partir de un italianismo reforzado- vulneran el contenido esencial de esa libertad y omiten los sacrificios exigidos por la cobertura de su núcleo inviolable.

Los valedores del Estado de Bienestar infringen un compromiso capital si no trasladan estas reflexiones a normas jurídicas de aplicación directa y -olvidando el rango y el empaque constitucionales de la libertad de empresa- privan a los jueces ordinarios del utillaje necesario para eludir escollos de presumible aparición. Ante tamaña exigencia social, la receptividad imaginativa de la jurisdicción tiene la última palabra. Sus lecturas ayudarán a cerciorarse de si los emprendedores -que a su cualidad de oferentes de trabajo deben sumar la voluntad inquebrantable de arrostrar contingencias que no les arredran-satisfacen sus funciones sociales o si crece el número de los empresarios a secas que las desatienden, porque, insensibles a la voladura controlada de sus efectivos humanos o cómplices de iniciativas semejantes, se abstienen de imprimir a sus procesos productivos la continuidad y robustez que detengan el hundimiento del empleo.

La libertad de empresa - a cuyo núcleo invulnerable pertenece la propiedad de los instrumentos y medios de producción- deja de ser un escueto derecho-facultad y soporta una carga coherente con la función social que le confiere el art. 33.2 CE. Esta consiste en usar de la flexibilidad para reanimar los procesos afectados por la recesión y mantener los puestos y las ofertas de trabajo cuya supervivencia se opone a los gestores de la operación repugnante de signo contrario. El contenido esencial -que ha de respetarse si los arts. 33.2, 38 y 53.1 CE se coordinan armónicamente- incluye el gravamen de atajar la virulencia de un achaque que, si se perpetua, arroja sobre el sedicente Estado de Bienestar las lacras del desprestigio general que denuncia la sociedad contemporánea -agredida por tales complacencias- y la posteridad ofendida y arruinada por ese descrédito.

\section{IMPORTANCIA DE LA SEGURIDAD JURÍDICA PARA CONSEGUIR, EN LO CONCERNIENTE AL ESTADO DE BIENESTAR, LA MODERNIZACIÓN DEL SISTEMA DE FUENTES DEL DERECHO OBJETIVO.}

La posición privilegiada de la seguridad jurídica en el contexto de la legalidad fundamental significa una pieza insustituible para el sano funcionamiento del Estado de Bienestar. El art. 9.3 CE participa a la ciudadanía y a los poderes públicos que, sin perjuicio del bloque de moralidad legalizada que alberga el TPCE (Título Preliminar de la Constitución española), la seguridad jurídica no se acoge superficial o tibiamente. Se vigoriza convirtiéndola en resultados perceptibles por cuantos asocian su concurso a la solidez de los derechos, las obligaciones y otras situaciones jurídicas que les gratifican. La seguridad jurídica formal-constante en el art. 9.3 CE-refuerza la médula del bienestar social y oxigena la confianza de los ciudadanos en el tino con que, aun sin considerarla un derecho fundamental, el constituyente la privilegia desde otras perspectivas. Transmite el general convencimiento 
de que siempre se dispondrá de medios aptos para pacificar y/o disolver los conflictos de intereses que rebasen la normalidad de las tensiones anejas a su fisonomía. Promete su supervivencia y crecimiento frente al retoricismo del extinto sistema paternalista autoritario que anticipó la fórmula del art. $17 \mathrm{FE}$ (Fuero de los Españoles de 17 de julio de 1.945, modificado por la Ley de 10 de enero de 1.967), declarando el derecho de los ciudadanos a una seguridad jurídica exigente de que todos los órganos del Estado actuasen según un orden jerárquico de normas preestablecidas que no podían ser objeto de interpretación ni alteración arbitraria. No hay constancia estadística de la aplicación y la frecuencia con que, desde entonces, se usó acertadamente de una proposición tan impecable. Luego especificada en el TPC.c. que -gracias al «sucedió mañana» de la sutileza reformista y no a la zafiedad del rupturismo- devino el desarrollo preconstitucional (¿?) de un criterio que, en virtud de la DD.3 CE (Disposición Derogatoria 3 de la Constitución española), disuadía de su derogación y alentaba su continuidad.

La garantía se proyecta sobre el porvenir, pues la seguridad jurídica material-valor del ordenamiento jurídico que incide en las alternativas de la acción transformadora- requiere observar una carga de recuperación. Un rescate impuesto a los poderes públicos que, con mal disimulada apatía, se desentienden de las desasosegadas peripecias de un Estado de Bienestar por el que -repicando a muerto-doblan aqui y ahora las campanas. Aumentan los desmanes de unas acciones globalizadoras que, pisoteando tantos y tan valiosos adelantos, quieren aniquilar lo que aun perdura de su creatividad inolvidable. La jurisdicción ordinaria está llamada a reprimir, en nombre de los compromisos inmanentes al cambio social, esas aviesas intenciones y restaurar los pilares de una seguridad jurídica cuyo detrimento augura las penurias de un futuro menos optimista. Se vive a la espera de un control judicial efectivo de los desórdenes globalizadores que, declarando una guerra sin cuartel al Estado de Bienestar, quieren exterminar, caiga quien caiga, lo que aun resta de sus promesas reductoras de la infelicidad de los seres humanos.

\section{DESAFÍOS QUE HA DE AFRONTAR LA JURISDICCIÓN ORDINARIA EN FAVOR DE LAS OPORTUNIDADES ACTUALES DEL ESTADO DE BIEN- ESTAR.}

Aunque el p. 10 EMTPC.c. deniega a la jurisprudencia el carácter de fuente del Derecho, la causticidad con que la doctrina de la justicia constitucional ha desautorizado algunas actuaciones de la jurisdicción ordinaria, distorsiona la imagen añorada para cohonestar los elementos del interés general que son la convivencia exenta de conflictividad desordenada, la colaboración tangible y solidaria y la generación de resultados positivos por los portadores de los intereses individuales y colectivos. Lejos de transmitir tranquilidad, esos acontecimientos -que tienen lo suyo de desconcertantesno obedecen a la contraseña que reza «de la contradicción sale la luz» ni 
al axioma filosófico del devenir, para el que «la guerra lo engendra todo y es la clave de cuantos lances y sorpresas depara la vida mundana». Sí que, en cambio, las divergencias alimentan reacciones escépticas. El parecer de una opinión pública desinformada y sin rumbo agrava las dolencias de un mal tan patente como lamentable. La declaración legislativa -que se echa de menos-de que la jurisprudencia ordinaria es algo más que un complemento interpretativo, se saludaría con elogios unánimes, pues añadiría un prestigio enorme a la tarea de dilucidar los conflictos - enojosos y embrollados- que provocan la interpretación y la aplicación de las normas jurídicas conforme a los hechos subsumibles en sus regulaciones. La sociedad se aprovecharía de una estimable adquisición, porque, al realzarse el cometido de la jurisdicción ordinaria, se acallarían los desasosiegos de las conciencias ignorantes y/o enfebrecidas por los antagonismos, se atenuarían las tensiones pendientes o a punto de incoarse, se racionalizaría el capricho de acudir por inercia a la justicia constitucional y se cancelarían sus incursiones -¿objetivamente inconstitucionales?- en los reductos de la jurisdicción ordinaria. Se cerraría, para la serenidad intelectual de casi todos y la normalización del Estado de Bienestar, el último capítulo de una pedagogía desaconsejable. Renacerían las oportunidades de eliminar los estigmas sociales y llamar a las cosas por su nombre. Nadie puede aceptar, sin invocar los fueros del sentimiento constitucional, la frecuencia con que - ¿desoyendo una de las garantías del art. 9.3 CE y acaso infringiendo la interdicción de la arbitrariedad de los poderes públicos?- la justicia constitucional acude a los arts. 14 y 24.1 CE para atestar un cajón de sastre que almacena los controles más heterogéneos del ejercicio de la jurisdicción ordinaria.

La integración pacificadora de las normas de Derecho objetivo sería irreprochable si, amén de fijarse la doctrina general sobre el caso, se coincidiese en los métodos aptos para que la jurisdicción ordinaria -competente en los diversos sectores del ordenamiento jurídico- colmase los vacíos pendientes de ocuparse por las normas llamadas a pormenorizar el laconismo de algunos principios y preceptos programáticos. Las concreciones esperadas y exigidas se aplazan indefinidamente o se abren paso demasiado tarde. El actual demérito del Estado de Bienestar no permite resignarse a perder esas expectativas. Se traiciona su artesanía programática si sus disposiciones generales no se especifican antes de que transcurra un tiempo razonable, más allá del cual la mora del legislador escandaliza y desatiende los intereses generales. No pueden perpetuarse situaciones en que los destinatarios de las normas jurídicas denuncian el olvido de unos intereses que, pese a su inobjetable legitimidad, se resienten de una desnudez afrentosa. La jurisdicción ordinaria viene obligada a liquidar una diferencia de trato -ayuna de justificación objetiva y razonable- entre los ciudadanos arropados por la regulación exhaustiva de sus relaciones jurídicas y los que sufren la orfandad de un desarrollo que indefinidamente se pospone. El art. 9.2 CE prohíbe perpetuar una casta de destinatarios desheredados o de segunda zona de las 
normas jurídicas azotadas por esa discriminación. Serían aprovechables los criterios que, según el art. 3.2 C.c., ofrece la ponderación de la equidad para fertilizar la suerte de unos intereses desvirtuados que mejoran de condición en cuanto la tutela judicial les califica de intereses vigorosos. Desaparecería el tratamiento discriminatorio de los agraviados por una resistencia injusta de la soberanía del Estado que, ante la dilación de algunos de sus países miembros, el Derecho judicial de la UE - por citar el modelo exigible- ha corregido ejemplarmente. Se extinguiría una especie vitanda de obligaciones naturales cuya prolongación estigmatiza a los poderes públicos que, abusando de su decisionismo político, las incumplen paladinamente.

La aplicación judicial del Derecho garantiza la entereza y el flujo regular de los valores del Estado de Bienestar. Se enfrenta a los traumas de la génesis del Estado compuesto y a la catarata de los eventos económicos que avituallan el concepto jurídico indeterminado de realidad social. El art. 3.1. C.c. -regla interpretativa y, además, susceptible de las relecturas que autorizan su revisión y puesta al día- ha de entenderse en el sentido de que, a diferencia del Estado unitario que presuponía una sola y única realidad social del espacio compacto de aplicación de las normas jurídicas, el Estado plural de las autonomías se compone de distintas realidades sociales. Se aprecian éstas al calor del espíritu móvil, estimulante de la voluntad evolutiva de las leyes que, en cada lugar y cada tiempo, induce a descubrir -trayéndolas a la superficie y no inventándolas arbitrariamente- las reformulaciones necesarias. Las realidades económicas -inherentes a la magnitud y los factores de la crisis- son conceptos jurídicos indeterminados que, auxiliados por los especialistas, los jueces ordinarios difunden mediante proposiciones arregladas a sus capacidades pedagógicas. No cabe constreñirse a los minimalismos de la sana crítica-que reitera el art. 348 LEC (Ley de Enjuiciamiento Civil de 7 de enero de 2000)- ni acatar ciegamente el parecer de los expertos, sino que se han de describir, minuciosa y persuasivamente, las realidades que -amén de la notoriedad de los sacrificios impuestos a una ciudadanía indefensaalojan los valores de contenido variable que influyen en los criterios evolutivos de interpretación. Los jueces ordinarios no son meros resonadores del saber especializado y, por imperativos de justicia, han de sumergirse en las realidades económicas que abarcan los supuestos de hecho -objeto de la prueba- y las normas de Derecho objetivo que se les aplican.

Las realidades económicas encierran un valor genérico de contenido variable que recaba muchas y llamativas precisiones de la jurisdicción.. La nostálgica tesis de que el juez es el intérprete de una civilización resalta lo excepcional y duro de las servidumbres causadas por una pavorosa recesión económica que no lleva camino de tocar fondo. El Poder Judicial no estaba avezado a los laberintos de estas excursiones interdisciplinares hasta que -al servicio solícito del Estado de Bienestar- le ha llegado el momento de penetrar en ellos. Defenderá, si a bien lo tiene, la verdad de una causa cuya ocultación denuncia -resaltando los embustes economicistas - la sociedad 
dañada por el reparto arbitrario de sus reducciones, y reprobará la ausencia de una información -veraz e inteligible- que, por precepto del art. 20.1 a) $\mathrm{CE}$, se le adeuda y, ello no obstante, se le escamotea.

\section{COMPROMISOS QUE LOS JUECES ORDINARIOS ESTÁN EN CONDICIO- NES DE ADQUIRIR PARA DIFUNDIR Y DEFENDER EL DERECHO JUSTO.}

La sustancia del sistema de fuentes del Derecho objetivo refrenda la tesis -reconfortante y singular- de que la verificación de la justicia material de las normas jurídicas precede a cualesquiera otras reflexiones relativas a su validez o a la regularidad formal de su proceso de generación. El mensaje del art. 1.1 CE conduce a esta conclusión meridiana, porque el valor supremo de la justicia material revela una opción sobresaliente y preferible entre otras concurrentes y llamadas a salvar las expectativas del Estado de Bienestar. Ese valor -que indisolublemente funde la igualdad y la libertad efectivas- vincula a los jueces ordinarios que, auxiliados por las técnicas que tienen a mano, pueden contener el alud de las leyes injustas y mantener aseados, gracias a su rechazo, los espacios expuestos a sus invasiones. Pese a lo indivisible y unitario de su imagen, la justicia es un concepto jurídico indeterminado que, a la hora de cuestionarse su definición más certera, tolera un pluralismo templado y acorde con la naturaleza de las cosas. Los valores superiores del ordenamiento jurídico -que enumera el art. 1.1 CEse resumen en la idea general de justicia, fruto de la igualdad y la libertad reales y efectivas que enaltece el art. 9.2 $\mathrm{CE}$, mientras que el pluralismo político es una subespecie de las mismas. La justicia es el valor supremo del ordenamiento jurídico y no cabe, antes bien desorienta, fragmentarla en modalidades o variantes. Otra cosa son las evasiones emocionales o retóricas que pugnan con esa integridad. De ahí, la posibilidad y la exigencia de que los jueces ordinarios suspendan la aplicación de las leyes injustas o, conforme al art. $163 \mathrm{CE}$, promuevan cuestiones de inconstitucionalidad para eliminar las contradicciones que, vulnerando frontalmente y no tan sólo erosionando los principios y/o preceptos de la legalidad fundamental, se divisan a primera vista. Aunque irreprochablemente promulgadas, las leyes injustas escarnecen un valor sobrepuesto al todo de esa legalidad y al resto del ordenamiento jurídico, a los que, según los arts. 117.1 CE y 1.1 LOPJ, el Poder Judicial queda exclusivamente sometido.

Ha ganado fortuna el parecer de que las leyes deben atenerse, con el vigor y exactitud posibles, al criterio de las demandas sociales que postulan la positivización o puesta en la ciudad de los intereses auspiciados por sus proposiciones. El error sustancial -que amenaza a la tarea de escoger las demandas sociales auténticas y apartarlas de las falsificadas-irroga a la causa del Estado de Bienestar un daño difícilmente resarcible, pues los perjuicios derivados de una identificación equivocada no se enjugan con las adquisiciones que tratan de compensar la degradación o impedir el posible desgaste. Cuando el legislador da el «si quiero» a las vehementes expresio- 
nes del decisionismo político parlamentario, la jurisdicción ordinaria puede preguntarse si no es precario o simulado el fuste de las demandas sociales traídas a capítulo y si este vicio no incurre en servidumbres que las confunden con tales preferencias. Pese a su legitimación o apariencia de tal, el sano sentimiento de la sociedad segrega razones bastantes para suspender la aplicación de unas normas que, sin haberse derogado, están destituidas de su valor vital. Las leyes sólo se derogan por otras posteriores, reza el art. 2.2 C.c., pero se consideran abolidas - lo que es tanto como inutilizarlas en perjuicio del intereses de sus destinatarios- si, pese a sus impecables apariencias, contravienen la voluntad mayoritaria de la sociedad pluralista en que, a tenor del art. 1.1 CE, se organiza el modelo del Estado social y democrático de Derecho.

La cita que, de pasada, dedica el art. 1.4 C.c. a los principios informadores del Derecho objetivo -sin exceptuar el de la búsqueda insistente y la veneración de la justicia material-reconoce la eminencia del Derecho justo que encabeza un ordenamiento jurídico caracterizado por la excelsa imagen de su cielo moral. Este anticipo es una norma en blanco que adquiere color y contenido si se repara en la cualidad de supremo valor del ordenamiento jurídico que el art. 1.1 CE confiere a la justicia. Circunstancia que, gracias a esa función informadora, permite a la jurisdicción inaplicar las leyes cuya experimentación revela los componentes de injusticia material que en ellas concurren.

De estarse a lo prescrito en los arts. 5.1, 6 y 7.1 LOPJ, el Tribunal Constitucional es el supremo artifice del Derecho aplicable y no sólo el máximo intérprete de la Constitución. Los recursos de amparo -cuya excesiva interposición se ha criticado y reducido en parte- fomentaron una aplicación -imprevista y masiva-de los arts. 14 y 24.1 CE, y provocaron revisiones -inéditas y un tanto peregrinas- del ejercicio de la jurisdicción ordinaria. El objetivo fiscalizador resultó del propósito de controlar las decisiones y las supuestas desviaciones ideológicas de una jurisdicción cuya depuración larvada se ensayaba por ese camino. Son palpables y, hoy por hoy, no llevan traza de moderar su acidez, los desencuentros entre una jurisprudencia ordinaria deprimida y los pronunciamientos de una justicia constitucional teñida de aspereza dialéctica cuando amonesta o desautoriza a la primera. Según el art. 5.1 LOPJ, su eficacia vinculante no exige reiterar la doctrina fijada que ha de prevalecer en el futuro, dimana de toda clase de procedimientos y anida incluso en las resoluciones interlocutorias. Para el art. 1.6 C.c., la jurisprudencia ordinaria descansa en la reiterada autoridad de lo resuelto, se genera con ocasión de los recursos extraordinarios que atañen a las dudas planteadas y se formaliza a través de una sentencia. A estas diferencias conceptuales se suman anécdotas de arte menor. La jurisdicción ordinaria ha multado a los Magistrados del Tribunal Constitucional por entender que algunas de sus resoluciones no estaban suficientemente motivadas. La justicia constitucional no ha devuelto al juez natural, en más de una ocasión, 
el conocimiento de asuntos que le competía en sede de jurisdicción ordinaria y ha declarado firmes las resoluciones que -tras prosperar el recurso de amparo interpuesto contra el acto impugnado- debían dictarse nuevamente a causa de la declaración de nulidad. Lo cual, quiérase o no, confisca el derecho -que reconoce el art. $24.2 \mathrm{CE}$ - al juez ordinario predeterminado en la ley y le reemplaza por una expresión innominada del principio de economía procesal.

La planificación democrática es el género próximo de una especie con que, entre luces y sombras, la UE bosqueja un orden público pensado para identificar y mitigar los males de la recesión, mostrando, de paso, el discutible europeísmo y la anarquía desestabilizadora de algún que otro de los Estados miembros. No se conciben la negligencia y la tardanza en afianzar sólidamente los pilares de Derecho necesario que, para no desintegrarse y ser fiel a sus fines, requieren las variantes de la aglutinación europea. Ha habido que llegar a un estado de alarma económica para que, a falta de previsiones y técnicas automáticamente correctoras de las demasías neoliberales, se haya disparado una guerra de nervios desedificante, promoviendo, a buenas horas, la perentoriedad de un orden público económico al que, desde un principio, los juristas y los economistas de pro comunitarios no dedicaron su reflexión más minuciosa. Sin criticar lo heterogéneo y laxo de sus fuentes, la situación de crisis económica ha impulsado a fabricar deprisa un Derecho necesario -indulgente con el rigor técnicojurídico de su elaboración- que ingresa en el ordenamiento jurídico comunitario. Vincula a la jurisdicción ordinaria que resuelve los casos en que sus anomalías requieren estar a esas limitaciones. Sus cortapisas -que cambian de un día para otro- dan idea de la precipitación y la ambigüedad con que se contempla una seguridad jurídica asediada por prejuicios políticos y -¿cómo no?- por la envergadura de los ajustes de cuentas subyacentes.

Las interacciones de la jurisprudencia ordinaria y la doctrina de la justicia constitucional plantean una hipótesis digna de examinarse en el debate sobre la subsistencia del Estado de Bienestar o su condena a un decadente porvenir. Según los arts. 117.1 y 160.4 y $5 \mathrm{CE}$, los jueces ordinarios están exclusivamente sometidos al imperio de la ley que interpretan y aplican conforme a los criterios hermenéuticos que les suministran el art. 3.1 C.c. y las aportaciones complementarias de la jurisprudencia. Los jueces constitucionales pueden pertenecer legítimamente a partidos políticos y sindicatos, siempre y cuando no ejerzan funciones directivas ni mantengan con ellos relaciones de empleo. La independencia que, no obstante esta singularidad, les exige el art. 159.5 CE, se condice mal con tales adscripciones y no les impone la renuncia a unas opciones sindicales y/o políticas anudadas a la militancia que se les consiente. Dista de prohibirles que, al decidir los asuntos cuyo enjuiciamiento les compete, sus motivaciones reflejen esa pertenencia y la proyecten sobre el razonamiento y el sentido de sus resoluciones. La independencia propiamente dicha exige que ninguna coerción exterior 
traspase el blindaje de la autonomía intelectual y sojuzgue la voluntad motriz de su decisionismo, pero no se refiere a las vinculaciones con las que el constituyente condesciende. El sometimiento exclusivo de los jueces ordinarios al imperio de la ley, que resalta el art. 117.1 CE, significa que sus pronunciamientos han de sustraerse a los titubeos o flaquezas que debiliten esa sujeción. ¿Qué decir del entendimiento de las normas constitucionales que, a causa de las adscripciones sindicales o políticas de los supremos intérpretes de la legalidad fundamental, colisiona con el alcance que -según los elementos de interpretación que reseña el art. 3.1 C.c.- los jueces ordinarios pueden otorgar al sentido propio de las palabras de las leyes y/o a la lógica comprensión de sus proposiciones? ¿Es admisible un derecho de resistencia judicial frente a esas eventuales interpretaciones? ¿No inquieta el silencio del art. 5.1 LOPJ, que algo pudo y debió, cuando menos, insinuar al respecto? ¿Cabe conciliar la independencia natural con las premoniciones de una imparcialidad en peligro? La serenidad jurídica del Estado de Bienestar no puede hacer oídos sordos al problema, que entonces irrumpe, de elegir una $\mathrm{u}$ otra de las variantes del Derecho justo. La independencia judicial de toda la vida, en cuanto inteligible e inequívoca, difiere de la independencia relativizada de los jueces constitucionales que -afiliados a sindicatos o partidos políticos y ante el estupor de los juristas- pueden explotar el instrumento de

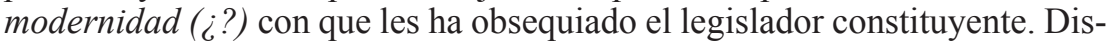
ponen de él para operar sobre el valor superior que, plasmado en la justicia, tolera evasiones conceptuales de asimilación intelectual muy enojosa.

En la intimidad de los cambios de impresiones y ocurrencias oficiosas que precedieron a la apertura del Tribunal Constitucional, circulaba el propósito de utilizar, como cajón de sastre, los arts. 14 y 24 CE para fiscalizar gracias a un uso alternativo del Derecho- la aplicación del Derecho objetivo por la jurisprudencia ordinaria y sustituir, llegado el caso, una o más de sus atribuciones soberanas. Por el momento, están servidos el enfrentamiento de ambas instituciones y el flaco servicio que la noticia de esta y otras novedades presta a la opinión pública sorprendida por ellas.

\section{PARTICULARIDADES DEL COMPLEJO SISTEMA DE FUENTES EN EL DERECHO DE LAS RELACIONES DE TRABAJO.}

Conviene desintoxicar el laberinto en que las fuentes del Derecho individual del trabajo se tratan como fuentes del Derecho objetivo y no como fuentes completivas o reguladoras de una relación contractual cuya exclusivo título es la ley que ha cuidado de tipificarla. La costumbre y los principios generales del Derecho no constituyen fuentes del Derecho objetivo, sino fuentes disciplinantes de un contrato estampado por el legislador en negro sobre blanco. Las otras fuentes son homólogas de las que el Derecho de las obligaciones contractuales utiliza para integrar relaciones jurídicas -véase el art. 1.258 C.c.- que, como resulta del art. $35.1 \mathrm{CE}$, expresan la equivalencia objetiva y no subjetiva de las prestaciones. Excepción al criterio general 
que, de no existir una lesión considerable, los arts. 1.274 y 1.293 C.c. predican de los contratos conmutativos y onerosos. La precisión obliga -muy enfáticamente- en una coyuntura de agresión contra la justicia conmutativa contractual de las relaciones individuales de trabajo y en el menoscabo de las iniciativas salvíficas del Estado de Bienestar. Queda claro que el art. 3.1 ET (Estatuto de los Trabajadores de 10 de marzo de 1980) no es una fuente del Derecho objetivo y sí una fuente completiva similar al art. 1.258 C.c.

Se yerra emplazando los convenios colectivos en el sistema de fuentes oficiales y pasando por alto que, lejos de ser ese su natural enclave, las normas dimanantes de su perfección pertenecen a un ordenamiento jurídico extraestatal de base institucional, asentado en el espacio geográfico de la soberanía del Estado y -he aquí el dato diferenciador- concurrente con un Derecho estatal del que no forma parte. No faltan las cavilaciones y las conclusiones dogmáticas que, obviando la evidencia de esta distinción, suministran un discurso embrollado y superfluo. Olvidan que uno es el ordenamiento jurídico del Estado, al que literalmente aluden los arts. 1.1, 9.1 y ¿146.1? $\mathrm{CE}$, y otro el ordenamiento jurídico sindical, fruto -como enseñan los arts. 7 y 37.2 CE- de la autonomía colectiva y no de la creación de los legisladores. Se suscita un falso problema si el concurso de normas de ordenamientos jurídicos independientes se confunde con los efectos de la jerarquía normativa en el interior de cada uno de los mismos.

\section{PLENITUD EXISTENCIAL DEL ORDENAMIENTO JURÍDICO EN EL PRE- SENTE DEL ESTADO DE BIENESTAR.}

He aquí algunas consideraciones sobre la oferta de plenitud existencial que insta el apoyo de la jurisdicción ordinaria. Atañe a cuestiones en que se echan de menos pormenores que los pronunciamientos de aquélla han omitido en el sector correspondiente del ordenamiento jurídico.

El Estado de Bienestar adopta una postura consciente y responsable que, apelando a la dignidad de la persona humana y a los requerimientos de la ley y el Derecho, confirma un postulado capital del cuerpo de doctrina que le ha inspirado siempre. Todo individuo es poseedor de una existencia que, además del presente, abarca las expectativas que acompañan a su crecimiento evolutivo. Esta existencia constituye una realidad defendible que -frente a los acontecimientos lesivos de su totalidad- justifica la reparación de cuantos daños amenacen o menoscaben un futuro por cuya continuidad se ha de velar con el esmero y atención peculiares de la diligencia impuesta por las circunstancias del tiempo y del lugar. El ordenamiento jurídico asegura, desde su perspectiva existencial, un sistema de fuentes revestido de la plenitud suficiente para llevar su proyecto al mejor de los fines. La plenitud indica que el Derecho no puede dar de lado a la cosmoeminencia o predominio de la dignidad de la persona humana sobre el resto de las cosas diseminadas por el mundo. También quiere decir que -a través del sistema real de las fuentes que aplican- los poderes públicos han de impulsar los cambios que, 
salvando un arsenal de decepciones y tropiezos, procuren a los beneficiarios expectantes las oportunidades óptimas de vivir dignamente. El Estado de Bienestar - plagado de animosidades que achican su acervo de bienes hasta extremos insospechados e imputables a la avidez mezquina de los hombresno desiste de regular la suerte de los intereses generales conexos con un bien común que cubre tres órdenes de necesidades. Ante todo, la coexistencia de las personas y comunidades que reivindican una libertad e igualdad efectivas o, lo que es lo mismo, equitativamente repartidas. Después, la colaboración de los individuos y los grupos significativos de una sociedad pluralista en la que toman el relevo los bienes más caros a la sensibilidad legislativa. Por fin, la participación en el aprovechamiento -con que la plenitud capitaliza el testimonio de la justicia distributiva material- y en el talante solidario de sus adquisiciones.

Ante la plétora de las realidades que le desafían, el Derecho objetivo ha de encarar los temas concernientes a la prosperidad, el fracaso y las demás vicisitudes notables de la Economía. El sistema de fuentes del Derecho objetivo es formalmente pleno, porque garantiza la respuesta esperada de su competencia en las contiendas confiadas a su resolución. No cuenta con caminos francos para ofrecer a la sociedad la suma de satisfacciones que -como expresiones emblemáticas del bien- tienden a difundirse en todas direcciones.

La promesa de instituir un orden económico y social justo figura en la dec. 1 Pr. CE (decisión 1 del Preámbulo de la Constitución española) y preconiza los que el cap. $3^{\circ}$, tít. I CE denomina principios rectores de la Política Social y Económica. Otros intereses han quedado, sin convincente explicación, fuera de la lista de derechos fundamentales revestidos de eficacia preceptiva directa. Algunos -como la negociación colectiva y las libertades sindicales de este nombre- lo han conseguido tardíamente, pues, gracias a los criterios contextual y sistemático de interpretación, la correlación de los arts. 7, 9.2, 28.1 y 37.1 CE ha permitido advenir, en este punto, a una reforma innominada. Aunque el elenco de los derechos fundamentales se acomode, en sustancia, a la naturaleza de las cosas y a sus presupuestos intelectualistas, no se sustrae del todo a las servidumbres del consenso político voluntarista y/o veleidoso.

Cuando la jurisdicción se detiene en esos principios rectores, advierte que, si uno o más de ellos penden de desarrollarse, hay que despejar las demoras y remover las trabas que, como indica el art. 9.2 CE, se deben a la omisión del poder público que ni los desenvuelve ni tiene el propósito de aplicarse inmediatamente a la tarea. El sometimiento al imperio de la ley -que, realzando la clave de la independencia judicial, recuerdan los arts. 117.1 CE y 1.1 LOPJ- apremia en situaciones que, como las ahora soportadas, describen el calvario que soportan las vicisitudes de la economía. La evidencia del dato no admite paliativos. Los jueces ordinarios advertirán que esos principios no aluden a las contingencias respectivas de una Política 
Social y una Política Económica, sino que indivisiblemente afectan a las de un tercer género que abarca los contenidos de ambas. Presumiendo un afán de corrección sintáctica y no de ligereza, el empleo del número singular y la conjunción copulativa parece intencionalmente elegido para redactar el encabezamiento del cap. $3^{\circ}$, tít. I CE y estimular las interpretaciones que este dato puede sugerir.

El buen fin de la Política que así se califica -emblema de las innovaciones del Estado de Bienestar- depende de los actos de individualización equitativa que el art. 3.2 C.c. autoriza para localizar las parcelas expectantes del Derecho justo y adentrarse en sus profundidades. La jurisdicción ordinaria se expone al reto de compaginar, con imaginación e intrepidez, las ideas que encumbren la trascendencia de la creatividad, la noticia -descarnada y veraz- del momento histórico que toca vivir y el alcance de una solidaridad colectiva que -aprovechando, de pasada, el tema de la protección del medio ambiente- el art. 45.2 CE declara indispensable en cualquier caso, a la manera cómo -ingenua e idílicamente- el art. 2 CE la predica de los espacios regionales y autonómicos. Acaso algo más al respecto pudo y debió decir el TPCE, desprovisto entonces de experiencias bastantes para ejercitar con eficacia la denuncia profética.

\section{FUNCIONES QUE INCUMBEN A LOS JUECES ORDINARIOS PARA AVA- LAR LA PAZ QUE NECESITA EL ESTADO DE BIENESTAR.}

La jurisdicción ordinaria ha de aplicarse a desterrar las deficiencias que vician la estructura del Estado de Bienestar. Pese al tenaz fracaso de las promesas hechas y de los arbitrios dirigidos a asegurar la paz perpetua, sus valedores la defienden a ultranza, porque su auténtica noción es mucho más que el enmudecimiento de las armas y/o el hueco que la guerra deja cuando pasa. La paz - erigida en una pieza decisiva del Estado de Bienestar-salta en pedazos cuando sus condiciones básicas de estabilidad sufren las amenazas terroristas, fruto del ordenamiento inmisericorde que compite con el potencial de las organizaciones supranacionales y mina los pilares de la soberanía del Estado. Huelga añadir, por sabidas de todos, otras consideraciones. Cooperando celosamente al sostenimiento de la paz, la jurisdicción reprime los atentados que turban su serenidad y elimina los remedos que defraudan su imagen.

Un ejemplo de permanente actualidad afecta a la reinserción social de la que -sin merma de las finalidades pacíficamente asignadas a las penas de privación de libertad- se ocupa el art. 25.2 CE. Resulta moral y jurídicamente indecoroso que la paz -recuperada tras el cumplimiento de la pena impuesta a quienes logran resocializarse- emane de arreglos transaccionales y nacidos de un consenso contrahecho que destruye su autenticidad y ofende a los perjudicados por su quebrantamiento. Reinsertarse es volver a la vida de la sociedad pluralista que, privando de libertad al sujeto inadaptado y luego arrepentido, le ha expulsado temporalmente de una o varias de las 
comunidades o suma organizada de individuos con quienes compartía su espacio habitable. Al no existir una disparatada presunción de veracidad que exima de acreditar otros puntos, la reinserción no se constriñe a una declaración de voluntad bastante para convencer de que se ha producido un regreso angelical y milagroso a la comunidad de origen. De exigirse sólo la constancia pública del arrepentimiento, cómoda de orquestar por los maestros del arte de fingir la voluntad de reinserción, faltaría el resto de los requisitos indispensables para cerciorarse del regreso efectivo y arreglado a los llamamientos restauradores de la paz. A la declaración individual del arrepentimiento o confesión de boca de la enseñanza catequética, se ha de sumar la credibilidad -inviable si no se han agotado los oportunos deberes de averiguación- de un compromiso inequívoco de no reiterar las conductas delictivas que, al desgarrar la convivencia y quebrantar la paz social, atentaron contra los valores centrales del Estado de Bienestar. Lo contrario supone, amén de un ejercicio de cándido cinismo, la impunidad del abuso del derecho fundamental reconocido en el art. 25.2 CE. No faltan pareceres -conexos con las coyunturas políticas- que, arguyendo que basta el arduo sacrificio ( $\mathrm{i}$ !) de formular perceptiblemente esa promesa, sugieren abstenerse de aumentar las condiciones impuestas a los arrepentidos de segunda zona.

En modo alguno pueden las cosas ser así. La jurisdicción ha de contar con elementos de convicción aptos para comprobar la verdad de la resocialización y rechazar la reinserción ficticia de quienes no demuestren una ruptura irreversible con el cuerpo y el alma de las organizaciones terroristas a que pertenecieron. La reinserción deja de serlo si, ciñéndose a lo visible del arrepentimiento, no concurren también el cumplimiento satisfactorio de la pena, la expiación personal y dolorosa que le imprime carácter, la cualidad de medicina para el alma que acusa un dejo de amargura, la ejemplaridad social del sufrimiento rehabilitador y la disuasión causada por el temor a verse privado nuevamente de la libertad recobrada.

Los jueces ordinarios señalarán los campos en que -para evaluar sus aptitudes liberatorias y didácticas- la opinión pública está pendiente de las intervenciones aguardadas con expectación. Estas predilecciones se concentran en los aspectos relevantes de la vida de la sociedad pluralista -también llamada sociedad civil- que, como apunta el art. 9.2 CE, fascinan el entendimiento y comprometen las energías de la persona individual. La opinión pública forma parte de todas o algunas de las realidades sociales a que alude el art. 3.1 C.c. y, si su contribución se echa de menos o se debilita, se malversa el uso interpretativo que de las fuentes del Derecho puede y debe hacer la jurisdicción al servicio del Estado de Bienestar.

La opinión pública es digna de fe cuando, al ejercitarse, se encuentra en posesión de la verdad y revela un dinamismo edificante. Lo primero, porque se reprueban los vicios de origen consistentes en que sus portadores sólo conozcan las versiones de una verdad esperpéntica o dosificada hasta el punto de sabotear la percepción esencial de su fisonomía. Lo segundo, porque, 
además de obedecer a esa veraz información, sus mecanismos -influyentes en los focos de acción y/o responsabilidad- exigen adoptar las medidas transformadoras del momento. Lamentablemente, no son así las cosas. Las fuentes mejor informadas no logran un convincente acceso a la verdad -cuyos datos de identificación se les escamotean- y se sumen en el desolador abismo de las voces sin voz que confiesan rabiosamente su derrota. A desfigurar la opinión pública cooperan los medios de comunicación entrenados en los hábitos deformadores que transmiten a sus audiencias y clientelas. No menos ayudan los profesionales de la Política que, trivializando la maldad contagiada por la mentira a las latitudes de la vida pública, la consideran un disculpable pecado venial y, lo que asombra más aun, degustan con fruición las filípicas moralizadoras ( $\mathrm{i}$ !) de algunos banqueros. También contribuyen los especialistas de las disciplinas del ser y del valor que profesan el minimalismo intelectual y aplauden los cambios de bandera. Es misión imposible obtener un nivel aceptable de bienestar social, si las colisiones y las algaradas de las opiniones públicas -divididas y erráticas- lo impiden de continuo.

\section{PERSPECTIVAS DIDÁCTICAS DE LA JURISDICCIÓN ORDINARIA EN LAS PERIPECIAS DEL ESTADO DE BIENESTAR.}

Las experiencias de la jurisdicción tienen lo suyo de función didáctica para ayudar a la supervivencia del Estado de Bienestar. Además de diagnosticar los excesos conflictivos y de aminorar sus tensiones, se trata de inventar -no imaginándolas volublemente y sí exhumándolas con la debida diligencia-ciertas obligaciones naturales cuyo punto y hora de exigibilidad social están en el horizonte.

Da ejemplo de ello la posibilidad -inferida del art. 5.1 LOPJ- de que la doctrina de la justicia constitucional encierre afirmaciones de pasada que, rozando las cuestiones en liza y aprovechando la ocasión pedagógica de analizarlas, se formulan porque probablemente no va a repetirse la oportunidad de su examen. Ningún espíritu sensible dejaría de elogiar las iniciativas que, en esa dirección, adoptase la jurisdicción ordinaria para reconfortar a la opinión pública e instruir a la ciudadanía. El discurso inventor de la Magistratura contemporánea predijo -con la ingenuidad de su entrada en escenaque el ejercicio jurisdiccional fomentaría la moralización de cuantos participasen en las controversias judiciales y atajaría las malas artes de quienes no tuviesen una directa responsabilidad en lo que llevasen a cabo en nombre de otros. Afirmaba que la presencia del público en las solemnidades del proceso recordaría a los jueces la gravedad de sus funciones, y la dignidad y alteza de su cargo. Los ciudadanos les atribuirían el celoso cumplimiento de un deber sagrado y elogiarían la pericia de su intervención en los debates. El rostro de los juzgadores reflejaría la inteligencia, la imparcialidad y la rectitud con que se entregarían a realizar sus cometidos. Un repertorio lisonjero que, ante las demandas de la modernidad, aconseja su revisión y puesta al día. 
Del papel de interpretar la civilización -en cuyas contradicciones se está sumergido- y desbrozar las realidades del mundo circundante, se predica una línea equitativa del pensamiento jurídico que -combatiendo la zafiedad de las obnubilaciones ideológicas- ayuda a los jueces ordinarios a convertir el Derecho en justicia, aun cuando la jurisdicción no ignore el concurso de otros agentes de la modernidad menos afligidos y dotados de mejores medios para alcanzar ese propósito. Recuérdese la importancia de los ámbitos sociales y económicos donde la grandeza y servidumbre de la mediación triunfa como sustitutivo procesal o equivalente jurisdiccional. No menos, el significado de la eficacia y justicia del orden natural de la equidad. Resulta inconcebible, si se añora de veras la vida en dignidad, trazar una inclemente línea divisoria entre el Derecho y las raíces moralizadoras que explican su movilidad y crecimiento. Correr las aventuras del Derecho justo es avanzar con una fortaleza acomodada a los imperativos de la prudencia y la templanza. No hay lugar disponible para las acrobacias del profetismo alborotado que suplanta los mandatos cursados a los legisladores por la conciencia colectiva y encumbra, como intereses generales, apetencias indignas de llevar ese nombre.

Por citar un ejemplo llamativo y vigente, la axiología del concepto de desarrollo sostenible es relevante cuando se versa su trascendencia universal y rueda la noticia de sus aportaciones a la causa de la justicia material. A la jurisdicción incumbe edificar un cuerpo de doctrina destinado a enlazar analógicamente la idea del desarrollo sostenible y el principio de irregresividad de las adquisiciones sociales con que los conquistadores sindicales de la participación y la democracia industrial contuvieron el ímpetu insaciable de la productividad. Dos bloques de bienes detestados por los francotiradores de la globalización y los adictos al pesimismo antropológico. No obstante la erosión de este dogma emblemático del Estado de Bienestar, la fe en su excelencia sigue en pie y enriquece sus objetivos de progreso.

La especulación confesional definió el desarrollo como la versión avanzada y progresiva de la paz entre los pueblos que en aquél habían puesto la esperanza reductora de sus desigualdades. El desarrollo sostenible -cuya adjetivación actual reclama un vocablo de sustitución coherente con su estatura conceptual- eleva a la segunda potencia el compromiso de no retroceder en la marcha iniciada, ni rebajar la cota de las aportaciones al engrandecimiento moral y material de las relaciones humanas. La jurisdicción -consciente de la multivocidad de ese adjetivo- no desoye los llamamientos de una justicia material que, a la luz del art. 1.1 CE, quiere asimilar el desarrollo sostenible al imparable crecimiento de las realidades que transfieren el signo de su modernidad al abolengo aristotélicotomista de la noción de bien común. $\mathrm{Su}$ acervo de intereses generales -indisociables de los fines del Estado de Bienestar- se compone de la coexistencia pacifica, la colaboración tangible y solidaria, y la participación en la efectividad de las virtudes que aumentan de tamaño y ocupan lugar. Esta y otras contribuciones judiciales resarcirían 
algunos de los daños que aquejan a un Estado de Bienestar cuya restauración solemne es inviable de momento, pues la codicia-obcecada y estulta-de los poderes económicos juega con ventaja cuando ultraja la fuerza moral de la dignidad de las personas que, pese a todo, prolonga su heroica actitud de rebeldía y se resiste a declararse derrotada.

\section{RELACIONES E INJERENCIAS DE LOS ORDENAMIENTOS JURÍDICOS QUE ASUMEN Y DEFIENDEN LOS VALORES DEL ESTADO DE BIENES- TAR.}

¿Hay un uno y único ordenamiento jurídico estatal o coexisten con él los respectivos ordenamientos jurídicos de las Comunidades Autónomas? De la contestación a la pregunta depende el tratamiento de algunas tensiones -recurrentes en los ámbitos estatal y autonómico-que son bastantes más de las imaginables. Una postura opina que, como se deduce de los arts. 1.1 y 9.1 $\mathrm{CE}$, el ordenamiento jurídico del Estado comprende y acapara el Derecho objetivo de las Comunidades Autónomas. Otra sostiene que el art. 146.1 CE -abordado sin retorsiones interpretativas- reconoce la existencia de sendos ordenamientos jurídicos en los marcos territoriales del Estado compuesto de las Autonomías. Tras recordar que los textos estatutarios son las normas institucionales básicas de cada Comunidad Autónoma, el art. 146.1 CE añade que el Estado los reconoce y ampara como partes integrantes de su ordenamiento jurídico. El enigma está en determinar a qué sustantivo conviene y se refiere el adjetivo posesivo «su», pues, obviada esta incertidumbre, hay dos alternativas. Según la primera, la protección es tautológica, porque los Estatutos de cada Comunidad Autónoma no se han disgregado del ordenamiento jurídico estatal y con él forman un todo compacto. Para la segunda, el reconocimiento y amparo -a cargo del Estado- no son meramente declarativos y sí constitutivos, ya que se añaden para disipar una duda. A su tenor, los ordenamientos jurídicos autonómicos - cuya individualidad no se discute- pueden adolecer de menoscabos corregibles mediante el apoyo que les presta un ordenamiento jurídico estatal del que se encuentran escindidos. La garantía - a cargo del Estado - se fundaría en que cada ordenamiento de una Comunidad Autónoma, diferenciado del ordenamiento general, disfruta de igual protección que, aun sin ser Derecho del Estado, le corresponde por mandato constitucional.

La redacción del art. 146.1 CE-muestra de la elasticidad del pluralismo político- no veda ninguna de ambas interpretaciones. La una explica el reconocimiento y amparo susodichos, porque, si los Estatutos de Autonomía se emplazan en el interior del ordenamiento jurídico estatal, huelga repetir lo que, siendo pacífico, no está en tela de juicio. Para la otra, la tutela y garantía de los Estatutos de Autonomía se debe a que, aunque separados del ordenamiento del Estado, sus ordenamientos jurídicos demandan un trato equivalente al que, para adjudicarles efectividad y evitar las discriminaciones arbitrarias, merecen las normas estatales. No es lo mismo entender esta 
cláusula como un aditamento superabundante, que nada nuevo dice, que como una garantía imprescindible para preservar la consistencia y extensión del Derecho objetivo de las Comunidades Autónomas. He aquí unos juicios alternativos de sustantividad y semejanza en que el mensaje de los arts. 2 y 9.2 CE bosqueja problemas que los jueces ordinarios tendrán acaso la ocasión de plantear y resolver.

Estos han de mostrarse receptivos -aunque la perspectiva lleve traza de ser, durante algún tiempo, una asignatura pendiente- al sistema de fuentes del ordenamiento jurídico comunitario que aplican en virtud de la eficacia preceptiva directa que les caracteriza. El ordenamiento jurídico de cada Estado miembro alberga el ingrediente del Estado de Bienestar que supone la pertenencia a la UE. Su actividad discurre en el marco de una atribución de competencias a las instituciones de la UE y de una restricción correlativa de los poderes de los Estados soberanos que forman parte de ella. Manejan un Derecho que, según la importancia de las cuestiones debatidas, cuenta con un valioso repertorio de instrumentos jurídicos que aligeran la carga de afrontar en vivo y en directo los interrogantes que aparecen. La jurisprudencia comunitaria atrae la decisión de las cuestiones que no se pueden congelar en la esfera doméstica de los Estados miembros. Sus aportaciones se valen de los criterios sistemáticos y los elementos finalistas de interpretación del Derecho europeo que entonces entra en juego. La adaptación del Derecho comunitario presupone unos ingredientes de rigor y de flexibilidad que el tecnicismo de las jurisdicciones nacionales puede coordinar, si a ello se aplica, conforme a la naturaleza de las cosas. El ordenamiento jurídico europeo dota a sus instituciones de un haz de competencias cuya perfección no se concibe sin la asistencia judicial complementaria. El papel aglutinante del ordenamiento comunitario informa los cuerpos de doctrina diseñados por la jurisprudencia europea $\mathrm{y}$, en su caso, por las jurisdicciones nacionales que prosperan gracias a unos pronunciamientos susceptibles de ulteriores mejoras y acomodaciones.

El Derecho comunitario impone a los jueces ordinarios de los Estados miembros cargas de responsabilidad que no siempre se observan. Con motivo de las controversias en que las normas del ordenamiento jurídico comunitario se han de tener en cuenta, los jueces nacionales -jueces naturales del espacio común europeo- suelen abstenerse de reparar en ello, pasan de largo y, olvidándose de su relevancia, aplican el Derecho o las normas autóctonas del Estado miembro que les ha investido del presupuesto procesal de la jurisdicción. Como si para nada contase un Derecho objetivo que prevalece jerárquicamente sobre el mismo. Más que por disidencias políticas o ideológicas concienzudamente asumidas, las jurisdicciones ordinarias se refugian en los Derechos nacionales por inercia y un tanto de comodidad que raya en la indolencia. Hay excepciones a la tendencia nacionalizadora cuando surgen dudas de notoria significación o se promueve una cuestión prejudicial para dilucidar las contradicciones interpretativas. El dilema «Derecho europeo o 
Derechos nacionales» ha provocado agudas reflexiones sobre el papel de las obsesiones castizas que ralentizan su comunión con algunos de los nuevos valores del Estado de Bienestar. Los jueces ordinarios tienen que corregir, llegado el caso, la inobservancia del deber de incorporar al Derecho de los Estados miembros las reglas del Derecho europeo derivado cuya transposición esté pendiente de llevarse a cabo.

Las mudanzas del sistema de fuentes del Derecho objetivo influyen en el pensamiento y las iniciativas de la jurisdicción ordinaria sobre los augurios del Estado de Bienestar, a las que, en la coyuntura económica de hoy día, afectan la movilidad y el espesor de los ordenamientos jurídicos tenidos en cuenta. El engrosamiento del sistema de fuentes y la penetración de ingredientes atípicos se explican porque las realidades económicas de la modernidad -apáticas, cuando no enemigas de la subsistencia del Estado de Bienestar- provocan la emergencia de una masa de Derecho objetivo que fluye aceleradamente de títulos heterogéneos y refractarios a una diáfana sistematización. Trátase de irrepetibles intuiciones, de genialidades asombrosas, de errores colosales, de osadas predicciones, de colisiones álgidas y de omisiones cuya causalidad histórica eficiente es muy difícil o imposible de reconstituir. Algunas perduran tenazmente y otras -que, ello no obstante, dejan huella- se señalan por su fugacidad. Hay estados de cosas irreversiblemente consumados, apariencias posesorias y situaciones de necesidad que, ascendiendo al nivel de la vida jurídica, rectifican y/o cambian el rumbo de sus orientaciones. Los fundamentalismos economicistas dicen rotundamente «no» al postulado clásico -axioma del normativismo obsoleto- de que los espacios del Derecho objetivo sólo se ocupan con el razonamiento silogístico que apoya la lógica de las conclusiones judiciales. Verdad que hoy se agiganta en los parajes de la Economía, donde abundan las existencias de un escaparate de lo momentáneo y apenas cognoscible, pero generador de consecuencias explosivas que escapan a los más esmerados y sagaces augurios.

Demuestra una imponente heroicidad la pasión por defender los valores residuales que la gestión del Estado de Bienestar - del que subsisten los despojos recompuestos, contra viento y marea, por sus valedores intrépidos- logre salvar de su agonía. Se pregunta si servirán de algo o se agotarán estérilmente los arrestos que -honrando la cosmoeminencia de la persona individual y la excelencia moralizadora de un Derecho objetivo empapado de justicia material en cuerpo y alma- cargan contra las desventuras que, a la vuelta de la esquina y junto a los sofismas arteramente cocinados para desmoronar su resistencia, amenazan a la familia humana. ¿Qué porvenir aguarda, al final de esa oscura desbandada, a sus pobladores empobrecidos e indefensos? ¿Acabará triunfando -como lema del señuelo globalizador-la predicción de que «a los que casi todo lo poseen, mucho más les será dado, y a los que poco o casi nada tienen, todo les será quitado»?

Las consideraciones recién hechas mezclan el relieve de las coyunturas y las estructuras económicas con el presente erosionado del Estado de Bien- 
estar y la labor que los jueces ordinarios pueden realizar en favor de sus componentes residuales o sustitutivos. La versión novedosa del Estado de Bienestar tiene que descansar -si el fundamentalismo economicista no sofoca su intento expuesto a naufragar y convertirse en utopía- en la salvación del humanismo mediante la aplicación equitativa del Derecho al servicio de la dignidad de la persona y del todo de sus exigencias. Hay que apropiarse muchos de los valores y los bienes cuya modernidad se aplaude y acentúa. No hay buena conciencia de la prosperidad si a la presencia respetable del hombre en la Tierra no acompañan -amén de una economía saludable y aliada con las aportaciones del pensamiento y de la acción- la soberanía del razonamiento que destierra los voluntarismos arbitrarios, la inmersión en la cultura que cada quien ama y fomenta sin aquietarse a los estragos globalizadores, la espontaneidad de la opinión libre frente a la parvedad o el raquitismo de tantos espíritus críticos, y la fertilidad del pensamiento divergente frente a la tosquedad del pensamiento único. Las cosas son así, aunque los partidarios del imperio tiránico de la economía se empecinen en asfixiar los impulsos que, confesando su amor a la verdad, proliferan y denuncian los engaños ocultos tras inofensivas apariencias. Obligan a indignarse cuantas veces - que ya son demasiadas e ingratas- se comportan como si esa doctrina antropocéntrica, lejos de ser irreprochablemente valedera, procediese de una especulación pasada de moda o delirante.

El Estado de Bienestar ha de esforzarse -con el respaldo de los jueces ordinarios- en añadir a su depósito maltrecho la modernidad de unas adquisiciones elegidas con posibilismo y pulcritud. A saber, la universalización de la justicia penal, la elevación de la libertad de empresa al rango de derecho fundamental condicionado por sus funciones sociales, el relieve de la seguridad jurídica a la hora de revigorizar el sistema de fuentes del Derecho objetivo, la elasticidad de los cambios que admite el contenido variable del Derecho justo, la singularidad y el emplazamiento de las fuentes del Derecho de las relaciones individuales y colectivas de trabajo, los testimonios de la plenitud existencial del ordenamiento jurídico, la defensa comprometida de la paz frente a las agresiones de la delincuencia organizada, las oportunidades pedagógicas de una jurisdicción innovadora y la utilidad de los ordenamientos jurídicos para promover, con especial solicitud, la continuidad del Estado de Bienestar.

Semejante rehabilitación precisa de la jurisdicción ordinaria para eliminar los obstáculos que redujeron el Estado de Bienestar al modelo -empequeñecido y burocrático- de garante de la seguridad jurídica y de las condiciones de la normalidad del mercado. Adjudicarle una atractiva configuración éticojurídica es el objeto de la acción transformadora que, en pos del éxito de la revolución venida de lo alto o desplegada desde el interior, vaticina el art. 9.2 CE. Aunque asociado a la nostalgia del paraíso perdido, ese afán elogia y acredita la lealtad con que sus portadores siguen fieles a la 
causa de la dignidad de las personas y al acervo de los derechos inviolables que, según el art. 10.1 CE, le acompañan indefectiblemente.

No es fácil conciliar estos objetivos con la desproporción de los bienes de un mundo que -en esta ocasión, muy de verdad- no es propicio a la sustitución cualitativa de los valores del Estado de Bienestar. El mundo achicado se encuentra hoy sustituido por otro mundo desplomado en el que, pulverizados sus elementos de sustentación, los encargados de su guarda se debaten entre diversas tentaciones. Es una la de dar la impresión de que nada nuevo está ocurriendo, porque siempre han padecido así las vidas personales y ha cambiado el destino de las cosas. Otra actitud intenta afrontar las conmociones con un mínimo de gallardía que no siempre parece acompañarla. Otra disfraza el dramatismo de las peripecias que se viven y causan la impresión de que alguien se está inmolando en aras de los mismos. Los expertos en Ciencias Sociales se entregan a las predicciones más varias y elegibles por los consumidores de su sabiduría. Los juristas esperan un mínimo refuerzo de aquellas realidades que llaman a emprender los rodajes urgidos por el Derecho justo. Los economistas brindan respuestas que -ante unos hechos consumados que nunca predijeron- declaran que han surgido contrariedades y/o sorpresas que prefirieron velar o denunciar a medias para no aumentar el empavorecimiento de la audiencia.

\section{BIBLIOGRAFÍA DE ORIENTACIÓN.}

CAÑo, J., «Desarrollo sostenible», Estudios jurídicos en memoria de José $M^{a}$ Lidón, Universidad de Deusto, Bilbao, 2002, pp. 791-803.

CAstedo, F., «El recurso de amparo constitucional», El Tribunal Constitucional, vol. 1, Ed. Instituto De Estudios Fiscales, Madrid, 1981, pp. 179209.

Del Vecchio, G., El Derecho Internacional y el problema de la paz, traducción de TruYol, A., Bosch, Barcelona, 1959.

Dessens, J., Essai sur la notion d'equité, tesis inédita, Toulouse, 1934.

ESCARPIT, R., Teoría general de la información y la comunicación, traducción de CARBo, A. y Sanagustin, Ed. Icaria, Barcelona, 1981.

Froнm, E., Escape from freedom, Ed. Farrar \& Rhinehart, Nueva York, 1941.

Galbraith, J. K., The affluent society, Ed. Houghton Mifflin, Boston, 1958.

Giddens, A., Sociología, traducción de Cuellar, J., Alianza Editorial, Madrid, 2002.

Giugni, G., Derecho Sindical, traducción de Vida, J. y Montalvo, J., Ministerio de Trabajo y Seguridad Social, Madrid, 1983.

Gordillo, L. I., Constitución y ordenamientos supranacionales, CEPC, Madrid, 2012.

Habermas, J., Historia y crítica de la opinión pública, traducción de Domenech, A., Ed. Gustavo Gili, Barcelona, 1994. 
HuFteAu, Y. L., Le référé legislatif et les pouvoirs du juge dans le silence de la loi. Presses Universitaires de France, París, 1965.

Levy, P., Les technologies de l'intelligence. Ed. La Decouverte, París, 1990.

Linde, E., El proceso de Bolonia: Un sueño convertido en pesadilla, Aranzadi, Cizur Menor, 2010.

Louis, J. V., El ordenamiento jurídico comunitario, traducción y edición de la Oficina De Publicaciones De la Comisión De Las Comunidades EuROPEAS, Bruselas-Luxemburgo, 1985.

LuCAS, P., «Política y justicia constitucionales», El Tribunal Constitucional, vol.2, Instituto de Estudios Fiscales, Madrid, 1981, pp. 1.483-1.550.

Martínez, M., «El Tribunal Constitucional como órgano político», El Tribunal Constitucional, vol. 2, Instituto de Estudios Fiscales, Madrid, 1981, pp. 1.785-1.821.

RAmonet, I., La tiranía de la comunicación, Ed. Debate, Barcelona, 2002.

Revel, J. F., El conocimiento inútil, traducción de Bochaca, J., Ed. Espasa Calpe, Madrid, 1993.

Rodota, S., La vida y las reglas: Entre el Derecho y el no Derecho, traducción de PIÑAR, J. L., Ed. Trotta, Madrid, 2010.

SAMPEDRo, J. L., El mercado y la globalización, Ed. Destino, Barcelona, 2011.

Sánchez Pego, F. J., Proyección de Don Eugenio Montero Ríos en la Administración de Justicia española, Ministerio de Justicia, Madrid, 1971.

SAnti Romano, S., El ordenamiento jurídico, traducción de Martin ReTortillo, L. y S., Ed. Instituto de Estudios Políticos, Madrid, 1963.

Sevilla, J., ¿Para qué sirve hoy la Política?, Ed. RBA, Madrid, 2012.

Sevilla, J., Capitalismo con rostro humano, El Mundo, 2 septiembre 2012, p. 9.

Treves, R., El juez y la sociedad, introducción de DiAz, E., traducción de LAPORTA, F. J. y Zaragoza, A., y revisión y anotaciones de MosQuera, L., Ed. Edicusa, Madrid, 1974.

Torralba, V. «Artículo 3 del Código Civil», Comentarios a las reformas del Código Civil. vol. 1, Ed. Tecnos, Madrid, 1977, pp. 165-194.

Wilenski, H. L. y LeBeAux, Ch. N. Industrial society and social welfare, Ed. Russell Sage Foundation, Nueva York, 1958.

WojcIK, K., «El concepto de las leyes injustas en la teoría de John Finnis», Estudios jurídicos en memoria de José $M^{a}$ Lidón, Ed. Universidad de Deusto, Bilbao, 2002, pp. 1.345-1.358.

Zorrilla, M. M., «El Derecho Natural como técnica de racionalización», Sociología para la convivencia, Ed. Zyx, Madrid, 1966, pp. 153-178.

Zorrilla, M. M., La invención de la Magistratura contemporánea, Ed. Universidad de Deusto, Bilbao, 1970. 
ZorRilla, M. M., «Inhumanidad del terrorismo en el espacio judicial», Estudios de Deusto, vol. 50/2, 2002, pp. 170-180;

Zorrilla, M. M., «Modernidad y moralidad de la mundialización», Estudios de Deusto, vol. 50/2, 2002, pp. 181-196;

Zorrilla, M. M., Protección judicial de las relaciones colectivas de trabajo, Ed. Gomilex, Bilbao, 2009.

Zorrilla, M. M., «Difusión extrajudicial del Derecho justo frente al reto del achicamiento del mundo», Estudios de Deusto, vol. 59/2, 2011, pp. 209235.

TITLE: Judicial suitability of the system of the sources of the Law to the Welfare State of today and tomorrow.

RESUMEN: La restauración integra de los elementos del Estado de Bienestar que se han degradado, es hoy una tarea imposible. Algunas aportaciones de la jurisdicción ordinaria pueden revelar nuevos aspectos sobre la esencia y el significado del Estado de Bienestar. Afectarían a la universalización de la justicia penal, al reconocimiento de la libertad de empresa como derecho fundamental y continente de funciones sociales, al relieve de la seguridad jurídica para revigorizar el sistema de fuentes del Derecho objetivo, a los componentes cambiantes que registra el contenido variable del Derecho justo, a la singularidad de producción de las fuentes del Derecho del Trabajo, a los testimonios de la plenitud existencial del ordenamiento jurídico, a la incondicional defensa de la paz frente a las agresiones de la delincuencia organizada, a las opciones didácticas de una jurisdicción innovadora y a la utilidad de los ordenamientos jurídicos para promover la continuidad del Estado de Bienestar. La erosión de los valores clásicos produce la emergencia de otros que pueden reemplazarles para evitar un desamparo social estrepitoso.

PALABRAS Clave: decadencia del Estado de Bienestar, sustitución de los ingredientes del Estado de Bienestar, aportaciones de la jurisdicción ordinaria, mediación del Derecho justo, acción transformadora.

ABSTRACT: The integral restoration of the ingredients of the Welfare State which had been degraded, is now an impossible task. Some aportations of the ordinary jurisdiction may reveal new aspects concerning the essence and the meaning of the Welfare State. They would comprise the universalisation of the criminal justice, the reconaissance of the market freedom as a fundamental right which implies social roles, the relief of the juridical security for invigorating the system of the sources of law, the changing components registered by the variable contents of the just law, the singularity of the production of the sources of the individual and collective Social Law, the testimonies of the existential plenitude of the law, the unconditional defence of the peace against the aggressions of the organized delinquency, the pedagogic options of an innovator jurisdiction and the profit of the law to promote the continuity of the Welfare State. The erosion of the classic values produces the emergency of another ones which may substitute them gradually for avoiding a noisy social crack. 
KEY WORDS: decadence of the Welfare State, substitution of the ingredients of the Welfare State, contributions of the ordinary jurisdiction, mediation of the just law, transformer effort.

Recibido: 12.11 .2012

Aceptado: 18.01.2013 